\title{
Women Within Hegemonic Masculinity: A Case Study on The Short Story “As'adu Az-Zaujaini” By Taufiq Al-Hakim
}

\author{
Zulfa Purnamawatia ${ }^{1}$, M. Hafidzulloh S.Mb ${ }^{2}$ \\ \{zulfapw_arb@ugm.ac.id\}
}

Arabic Literature, Faculty of Cultural Sciences, Universitas Gadjah Mada Sosiohumaniora Street, Bulaksumur, Yogyakarta 55281, Indonesia ${ }^{1}$, Liteary Studies, Faculty Of Cultural Sciences, Universitas Gadjah Mada, Sosiohumaniora Street, Bulaksumur, Yogyakarta 55281, Indonesia ${ }^{2}$

\begin{abstract}
Duality between feminine and masculine is a conceptual scheme regarding the tendencies of gender class which generates hegemonic power. Since the age of ignorance (Jahiliyah) to the modern era, Arabic literature has been narrating female characters. However, the characterizations of women often present gender intersection entities that lead to social stratification. The current research focuses on the hegemonic masculinity experienced by the female figure in the short story "As'adu az-Zaujaini" by Taufik AlHakim and its relationships with social, economic, and family issues. It employs a feminism approach under the perspective of R. W Connel with descriptive qualitative research methods. The hegemonic masculinity that the male character play in the story illustrates a hierarchical situation based on gender differences. This situation leads to the cultural domination attitude. The results of this study prove a hegemonized female character by the cultural constructs of the male character. Hegemonized, the female character does not just remain silent. She keeps moving, being more progressive, by making breakthroughs and resistance against the shackling hegemonic masculinity. This action affirms that a woman is not only a subject to the normative structure between husband and wife, yet she can move outside and exist in the public sphere.
\end{abstract}

Keywords: Hegemonic Masculinity, Resistance, Feminism, R.W Connell

\section{Introduction}

Halim Barakat and Ghada Karmi noted that the characteristics of the society and culture of Arabs tend to be patriarchal (Patriarchal Relationship) [1][2]. Their character typology is formulated due to the ideological construct of socio-cultural and political factor that has been developing among their social life. Such pattern, according to Illich and Hayat \& Maifhahus will formulate a consensus about the social relationship set by a group of men with full control upon their social life [3] [4]. Besides, it could potentially become an embryo for the growth and development of cultural particularization due to gender differences. As a result, the life pattern and the relationship conjure up stereotypes against women - suppression in culture, nature, and existence, having no power to act as self-determining and self-positioning.

The structure and social relationship which are under the gender differences in the cultural tradition of Arab society have successfully transformed many aspects and elements of their lives, one of which is literature. The intellectual development in the field of literature leads to 
diverse discourse struggles. For example, the presence of two figures between men and women in the literary works. Both figures are related to the symbolic and ideological construction of the author interpreted through the characterization style or subjectification in narrating the figures. Udasmoro reveals that the female figure represented in a literary work is always under the auspices of the male figures [5]. Stone-Mediatore notices that the narrative of a literary text related to women deals with the issue of discourse hegemony [6]. A text is the result of abstraction from the complexity of social phenomena. Thus, the struggle of both figures in the literary work is no longer limited to the intrinsic elements that must be included in the prose, yet it also has a high discourse level.

Women's representation is the latent form of hegemonic masculinity concept perpetuated to earn the privilege so that the women's image cannot be separated from their nature as people who experience subordination. Therefore, the practice of maintaining hegemonic masculinity is commonly found in the social life of the Arabs, obviously inherently institutional and noninstitutional improvisation and intervention within. On the other hand, the nature of women is taken for granted; the applicable law is in accordance with the normative dogma. The religious discourse shackles, perceived as the will of God under the interpretation of the holy scripture, lead women to be inferior [7]. Therefore, what is prevailing among Arab society is the marginalization of women, placing them in the domestic realm, and they do not deserve the public space.

Some research related to the hegemonic masculinity by utilizing feminism literary criticism approach are conducted by [8]. The masculinity reflected in the literary works are also related to the socio-cultural interpellation and conventions to find the relationship formulation among societies with various improvisations of the elements. According to Perwita [9] such conditions might spark the demands for the great fight for equality and remove all the stereotypes about women as the inferior parts of society. Because masculinity is associated with socio-cultural, economic, and political structure, the dominance and hegemony of masculinity deals with class or social stratification among male figures. Wardani [10] finds that the struggle for masculinity is not only about women and men. Masculinity also applies among men to prove who is the most dominant.

Under the above description, this article formulates some problems to discuss. The first, how are the masculinity dominance and the male figures narrated by the author in the short story. The second, how is the hegemony practiced among the people who are tendentious towards the gender differences. The essence of gender differences is no longer about biological issues. It is shifted and reaching out different social construction or intersection and interconnection under the gender differences.

This article aims to delouse the struggle of men and women figures in the short story "As'adu az-Zaujaini". In addition, the tendency on the narrative of male figures proves a hegemonic action based on gender differences. Hegemonic masculinity lies not only within the private sphere or at home. It manages to structure the activity of the woman figure from the social life. Therefore, this article will discuss the struggle for the hegemonic masculinity formulated from the culture of Arab society.

To answer the above questions, the current research employs the feminism theory of R. W Connell, which specifically refers to the hegemonic masculinity. Hegemonic masculinity is a view on the politic of masculine groups who always use and practice their power and reputation against the feminine one. These conditions will eventually construct a cultural pattern and belief that all social activities will be easily undertaken through masculinity. Hegemonic masculinity does not only concern on in the internal affairs, but it has managed to dominate the structure of 
government. As a result, Connell, [11] the tendency of masculinity is more visible, and it indirectly excludes feminine groups although the practice is always coercive.

Connell, [11] once the masculine becomes dominant, the social structure will be continuously reproduced from the smallest to the largest scope. For Connel, the difference between masculinity and femininity has been made on the treatment since they are kids by giving restrictions according to the gender. Gender is termed as a social fact [11]. While sex is biological. Often individuals who have a masculine gender are treated and built into a strong personal. They should not cry and compete with other men within social relationship. The mindset or paradigm will keep moving towards a wider scope of politic, economy, and culture. If those elements are successfully achieved, women will experience an exclusion and find no chance to show his nature as an individual who is not supposed to be limited by any kinds of social construction.

The relationship complexity constructed between men and women raises the term dominant and subordinate. Connell, [12] explains that masculinity difference formulated by the social relationship creates hegemonic masculinity. Hegemonic masculinity is not type of character that is absolute and similar everywhere. On the contrary, masculinity occupies the hegemonic position in the social relationship of the society, a position which is always contested. The construction of gender role played by every individual will affect on the role disproportion in the public sphere. Men are perceived to have a bigger role then women. Men dominance significantly depicts that the woman figure is one level lower. Feeling more powerful over women, men tend to use it not only vertically but also horizontally in the social life.

\section{Research Methods}

Research method, according to Faruk [13] is a process to acquire knowledge about the nature of the research subject. The subject of the current research is the short story titled "As'adu az-Zaujaini" by Taufiq Al-Hakim. The primary sources are the sentences and paragraphs in the short story. Then, various literary works, books, and scientific papers are used as the secondary data validated with the primary source. The next step is data analysis which is an extension of human mind because this stage essentially aims to explore the relationship among the data [13]. After the research variables have been synchronized in the data collection process, the collaborative relationship between the variables will be rooted.

\section{Results and Discussion}

\subsection{The Cultural Production of Masculinity Values}

Literary works do not only function as a product of certain culture but rather a medium that potentially becomes the imaginary world for the socio-cultural construction of particular society. The social constructs internalized in the literary works will obviously bring a particular ideology because the hegemonic perception of masculinity is perceived to be free from the limitation of social values [14]. Further, this condition reveals back the perception of masculinity construction that leads to a gap or social distance that determine a binary class and life pattern fragmented by gender differences [15] [16] [17] [18]. Social relationship formulated from gender differences will create a paradox of a neutral attitude in practical sense, or in the reproduction social order that expresses a particular paradigm [19]. 
Such model of social relationship denotes that cultural domination is inevitable. Cultural domination occurs unconsciously, and it is considered consciousness as revealed in the following excerpt of the short story "As'adu az-Zaujaini".

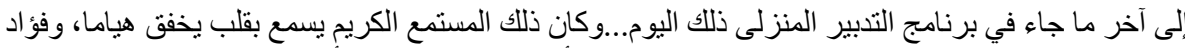

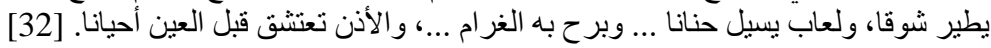

The man keeps listening to the family kitchen show carefully on that day until the end. He listens to the program in a heart pounding. Pssst...he was drunk in love! His heart was flying for desperately longing. His saliva seemed to flow...beautiful...he really had sunk in the ocean of love. Because, sometimes one's words are true, love will come from the ear before the eye.

The above quote describes the daily activities performed by the male figure. The activity is listening to the program on a radio hosted by a woman he didn't know before. Listening to the program with a high enthusiasm, he feels something has to fulfill. The feeling of lack brings him into a feeling of love to the girl who hosts the program. What causes the emergance of love to the radio host is not explicit told.

The expression and feeling of the man prove that to love a girl does not need a long process. What he wanted seems inevitable to realize. He believes that he is one level over the girl in the social stratification. Thus, he feels that the man is entitled to determine the target he wants and that the woman has to be the object.

$$
\text { لا بد لم بطق صبر ا وقام إلى أهله بعلن إليهم: }
$$

He also could not bear...he must convey the feeling to his family, "I believe, I have to marry that woman!".

The decision that he should marry the girl who became the host at the program brings up the perspective that he, as a man, can control his body, and her body can be conditioned by him. In this context, masculinity tendency becomes a paradigm which breaks the independence of the woman character who seems and inevitably receives the proposal to get married with the man. The dependency of women inherently lies in the cultural aspect that a man is the master of the hegemony [20]. A man can control it as he wants.

Therefore, the social construction applied under the structure of masculinity is not conscious, and it becomes a social reality based on the basis of gender differences. Besides, it becomes a man's expression within the social scope of performative of acts [21] [24]. The will to marry the girl who works as a radio host is an expression of power. The power is not a political repressive action but rather an instrument that plays through cultural aspect. That the position of a man, with all his masculinity, reserves the right to control everything.

\subsection{Subordination and Marginalisation}


The discourse structure of gender must consider the social aspect of an individual internalized in his/her environment, and it functions as the basis for his/her agent in the social structure [23]. The discrimination against women due to some histories or interpretations initially comes from the past views against women who are stereotyped with the nature of motherhood. Thus, when something against the stereotype happens, woman marginalization will appear. The interpretation of the woman stereotype drives the emergence of gender inequality [24]. Women who are relegated to the private sphere and lives within patriarchal environment becomes invisible in the public space.

$$
\begin{aligned}
& \text { فنظرت إليه العروس طويلا، ولم تجب...... - } \\
& \text { ومررت الأيام الأولى من أيام الزوجة...و العريس يتقلب على } \\
& \text { الثوق ويتقلى... منتظر اليوم الذى تدخل فيه زوجته المطبخ، وتلبس فوطها، وتشمر عن ساعديها، } \\
& \text { تطبخ له تلك الأصناف الثهية التى طالم شنفت أسماعه بوصفها التهائ اللذيذ في الر اديو. [32]. }
\end{aligned}
$$

"The bride was just staring at her husband for a long time. However, she did not answer. Until finally, the first days of their family passed by. The groom could not withstand his longing, waiting for the day, where his wife entered the kitchen, used an apron, folded her long-sleeves and cooked very delicious food...Yes, the very delicious food that he always listened to on the radio nicely."

The will of the male figure in the above excerpt illustrates that he very much hopes that his wife uses the cookware to prepare food for him. Using the cookware at home, he expect that the girl works like what he used to do when hosting the radio program. At the same time, of all the attributes that that the girl show up is an action to label that she should be able to apply what she usually delivers on the radio. The men, as a husband, also feels that he is entitled to control all the daily activities of his wife. The action has affected the paradigm of the wife, and when she cannot afford to fulfill the husband's will, she is considered breaking her duty as a wife. The role of the game of masculinity [25] which is constructed by social structures and normative stereotypes, will factually impact on the individual problematic attitude, and it penetrates into the life dimension the husband and wife.

The normative experience that successfully constructs the husband's perspective towards his wife can also affect how he positions himself within the family. To discover it, we need to see his actions, not only as a husband but also the way he represents hegemonic masculinity that has been strongly rooted from the cultural life construction. Wheaton [26] explains that gender is not only learned and negotiated, yet it has a fluidity that can incarnate in various aspects of life. Maclnnes [27] affirms that masculinity has become a social identity that presents a hierarchal level of social structure. Furthermore, the practice of domination is a process of oppression and exploitation against women [28].

\subsection{Between the House and Radio Station: A Space Negotiation}

The political space constructed from the complexity of gender issues results in a distance between the masculine and feminine. Because the fluidity of the space has been set by the dominant, it is not only derived from the gender aspect. Bonvillain [29] sees that the role of gender cannot be separated from the behavior and ideology which are interrelated with an individual development as a social being. Paradoxically, it seems to be a common sense to the social practice that demarcates boundaries as an instrument of symbolic violence [22]. The exclusion system will inherently reach out the identity and ideology issues, so the space 
constructed can be controlled. Therefore, the space is seen from the gender relationship to reveal women's role in "As'adu az-Zaujaini". The concept can be known from the presence of two spaces, the house and the radio. We can see it in the following excerpt.

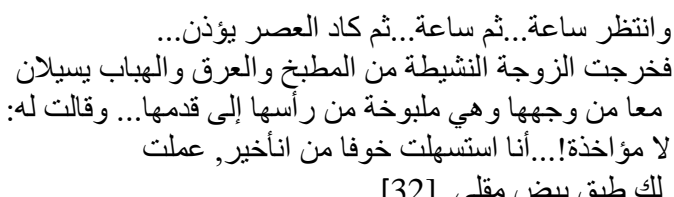

]32] للك طبق بيض مقذأنى

The husband kept waiting. Until the time for asr prayer was coming. Finally, his wife walked out of the kitchen. Sweat fused with smoke flowed down her face. The husband looked at his wife from feet to head. The whole body was wet of sweat. Then, the wife said "I'm Sorry! I just cook this. I cook a simple dish for fear of being late. So, I make fried eggs for you.

In general, the devotion of a wife to her husband is a reasonable action, so it cannot be countered with another opinion. This is how a wife should be. Preparing the dish for her husband, the woman character had tried to do best. However, the fact went on the other way around. She only cooked fried eggs to serve her husband. Through the hard effort, she had made the process to be the ideal wife as what most women commonly performed. For her husband, this action is considered an obligation for his wife because he must be the servant of his stomach. When status is the servant of the stomach, her existence as a woman within the marriage is reduced. Thus, once her service does not conform with the husband's expectations, disappointment appears from the way he looks at her.

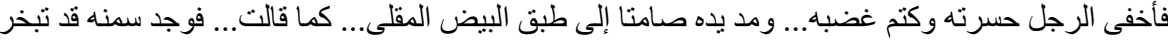

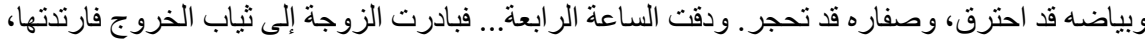

$$
\begin{aligned}
& \text { و وانطلقت مسر عة كأنها على مو عد هام. [32] }
\end{aligned}
$$

The husband tried to hide the disappointment and anger. He extended his hand without any words to reach the plate with eggs brought by his wife.... It was 4 o'clock in the afternoon, and his wife immediately cleaned up and wore nice clothes. After that, he came out immediately, as if she had an appointment with a very important person.

By facial expression, the husband indirectly showed a lack of acceptance towards the treatment. However, the disappointment was no longer a reason for his wife to leave for the radio station where she works. Time was running until afternoon; the wife must have moved to another space to continue his career as a radio announcer. The depiction of the woman's character who changes clothes to adjust with her double roles narrates that a woman also has individual rights. Therefore, the liberation process performed by the wife in the above excerpt is a resistance against the values that lead to the domestication of women's rights.

$$
\begin{aligned}
& \text { وما و افت اخامسة و الربع،حتى سمع الزوج المسكين صوت امر أته الحنون يتصاعد من الاديو ... و أطرق الزوج }
\end{aligned}
$$

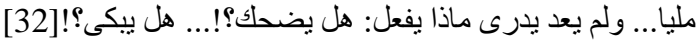

Then, the husband, with his grief and disappointment, listened to the radio program again at 4.15 p.m., hosted by his wife. At that time also, the husband looked 
disappointed and sad...he did not understand his condition at that time, what he should do, whether he needed to laugh or cry.

The above excerpt shows the disappointment expression of the husband to find out that his wife is dominant, choosing to work outside the house. Keeping the freedom of having activities outside of the house for the wife is basically a resistance against her husband as the representation of the hegemonic masculinity in general. Meanwhile, the husband as the family head does not force, stop, or forbid his wife to work in the public space. It indicates that the author of the short story raised the dignity of women as individuals who have equal rights after getting married. Therefore, [30] literary work does not only come from individual aspects, yet it also plays as a mediator to show negotiations, especially from Arabic literature. Besides, the negotiation is a negation against the concept of space and role separation attached to the female characters in the literary works.

Furthermore, the negotiation offered in the whole story is to posit a woman as a pure human who is not co-opted by various interests, either domestic or public. Majid [31] explains that Arabic literature nowadays has contributed to the development of women's liberation movement perceived to be always under hegemonic power. Finally, the liberation process and efforts do not only appear at a particular moment, but it shows up in action. It is possible to achieve equality, fighting against hegemony.

\section{Conclusion}

The social relationship among Arab society is culturally constructed from patriarchal system. They tend to reconstruct the culture to maintain that the position of men is higher, more dominant, and superior to that of women. Therefore, social life polarization affected by gender differences is commonly found. The polarization does not only work in the internal or domestic area, but it successfully reaches up to the external or public sphere. The impact of the differences in the social relationship of the Arabs from the concept of gender bias creates a mindset of women's existence in the public sphere. Women no longer have a total freedom to express their mind to the broader space.

They are only experts in the domestic area. Of the social relationship dominated by a patriarchal group, women in Arab gradually bring about transformation to explore their freedom in the public sphere. The main female character in the short story shows that women also have the right to exist in the socio-cultural and political sector. Arab women have the authority to maintain their existence to avoid any domestication.

\section{References}

[1] Barakat, H, The Arab World: Society, Culture, And State. Univ Of California Press, 1993.

[2] Karmi, G, Women, Islam, And Patriarchy. Feminism And Islam, 1996.

[3] Illich, I, Matinya Gender. Yogyakarta. Pustaka Pelajar, 1998.

[4] Hayat, E., \& Maifhahus, S, Perempuan Multikultural: Negosiasi Dan Representasi, Jakarta: Penerbit Desantara 2005

[5] Udasmoro, W, Dari Doing Ke Undoing Gender: Teori Dan Praktik Dalam Kajian Feminisme Ugm Press, 2018. 
[6] Stone-Mediatore, S, "Chandra Mohanty And The Revaluing Of "Experience", Hypatia, 13(2), 116 $133,1998$.

[7] Latifi, Y. N., \& Udasmoro, W, "The Big Other Gender, Patriarki, Dan Wacana Agama Dalam Karya Sastra Nawāl Al-Sa'dāwī", Musãwa Jurnal Studi Gender Dan Islam, 19(1), 1-20, 2020.

[8] Ariani, D., \& Udasmoro, W, Narasi Maskulinitas Dalam Le Rocher De Tanios Karya Amin Maalouf. [Yogyakarta]: Universitas Gadjah Madq, 2013.

[9] Perwita, Ratnanggana Ausiyyah Mustika, Representasi Heteronormativitas Sebagai Relasi Gender Hegemonik Di Dalam Novel Seri Crossfire Karya Sylvia Day. (Thesis). FIB Universitas Gadjah Mada, 2019.

[10] Wardani, A. Hegemoni Maskulinitas Dalam Under The Greenwood Tree Karya Thomas Hardy. Jurnal Satwika, 2, 68. Https://Doi.Org/10.22219/Js.V2i2.7988, 2019.

[11] Connell, R. W., Masculinities. Polity, 2005

[12] Connell, R. W., \& Connell, R, The Men And The Boys. Univ Of California Press, 2000.

[13] Faruk, H. T, Metode Penelitian Sastra: Sebuah Penjelajahan Awal. Pustaka Pelajar, 2012.

[14] Budiastuti, A. B. A, "Konstruksi Maskulinitas Ideal Melalui Konsumsi Budaya Populer Oleh Remaja Perkotaan", Mozaik Humaniora, 14(1), 8, 2014.

[15] Kimmel, M. S., Hearn, J., \& Connell, R. W, Handbook Of Studies On Men And Masculinities. Sage Publications, 2004.

[16] Trautner, M. N., Kwan, S., \& Savage, S. V, Masculinity, Competence, And Health: The Influence Of Weight And Race On Social Perceptions Of Men. Men And Masculinities, 16(4), 432-451, 2013.

[17] Ferree, M. M., Ferree, M. M., Lorber, J., \& Hess, B. B, Revisioning Gender. Rowman Altamira, 1999.

[18] Udasmoro, W,Paradoksalitas Pemosisian Perempuan Novel Colomba Karya Prosper Merimee, Jurnal Kawistara, 5(1), 2015.

[19] Bourdieu, P, The Logic Of Practice. Stanford University Press, 1990

[20] Kuhlmann, E., \& Annandale, E, The Palgrave Handbook Of Gender And Healthcare. Springer, 2010.

[21] Hood-Williams, J, "Gender, Masculinities And Crime: From Structures To Psyches", Theoretical Criminology, 5(1), 37-60, 2001.

[22] Bourdieu, P, Masculine Domination. Stanford University Press, 2001

[23] Risman, B. J, "Gender As A Social Structure: Theory Wrestling With Activism". Gender \& Society, 18(4), 429-450, 2004.

[24] Fakih, M, Membincang Feminisme: Diskursus Gender Perspektif Islam. Risalah Gusti, 1996.

[25] Pleck, J. H. The Gender Role Strain Paradigm: An Update, 1995.

[26] Wheaton, B, "New Lads"? Masculinities And The "New Sport" Participant. Men And Masculinities, 2(4), 434-456, 2000.

[27] Maclnnes, J, O Fim Da Masculinidade, 1998.

[28] Sultana, A,. "Patriarchy And Women S Subordination: A Theoretical Analysis". Arts Faculty Journal, $1-18,2010$

[29] Bonvillain, N, Women And Men: Cultural Constructs Of Gender. Rowman \& Littlefield Publishers, 2020.

[30] Mahmood, S, Politics Of Piety: The Islamic Revival And The Feminist Subject. Princeton University Press, 2011.

[31] Majid, A, The Politics Of Feminism In Islam. Signs: Journal Of Women In Culture And Society, 23(2), 321-361, 1998.

[32] Al-Hakim, Taufiq, Arinillah. Kairo: Daar Mishra, 1953 